Indexed by

\title{
Scopus
}

\section{EFFECT OF RECYCLED MATERIALS AND HYBRID FIBERS ON THE PROPERTIES OF SELF-COMPACTING CONCRETE}

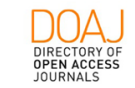

Crossref

KOBSON

\section{Eethar Thanon Dawood}

Northern Technical University, Technical College of Mosul,

Building and Construction

Department,

Mosul, Iraq

\author{
Maysam Salah Fathy \\ Al-heally \\ Northern Technical University, \\ Technical College of Mosul, \\ Building and Construction \\ Department, \\ Mosul, Iraq
}

Key words: recycled concrete, crushed red brick, ceramic aggregate, ceramic powder, SCC

\section{Cite article:}

Eethar, T. D., \& Maysam, S. F. A. [2021]. Effect of recycled materials and hybrid fibers on the properties of self-compacting concrete. Journal of Applied Engineering Science, 19(1), 262 - 269. DOI: 10.5937/jaes0-28558

8oogle

Online aceess of full paper is available at: www.engineeringscience.rs/browse-issues 


\title{
EFFECT OF RECYCLED MATERIALS AND HYBRID FIBERS ON THE PROPERTIES OF SELF-COMPACTING CONCRETE
}

\author{
Eethar Thanon Dawood*, Maysam Salah Fathy Al-heally \\ Northern Technical University, Technical College of Mosul, Building and Construction Department, \\ Mosul, Iraq
}

Self-compacting concrete (SCC) has many properties comparing to conventional concrete and represents a good choice towards sustainability. The use of different recycled materials contributes to seize the negative impact of huge amount of waste on the ecosystem. In this study, locally available materials have been used as partially cement replacements. Such materials including ceramic waste powder (CWP) and glass powder (GP) in addition to fly ash with total cement replacement of $30 \%(12 \% \mathrm{CWP}+8 \% \mathrm{GP}+12 \% \mathrm{Fly}$ ash) have been found to increase the compressive strength by about $7 \%$ compared to the control SCC. Normal aggregate was replaced by recycled aggregate with different recycled aggregate which are Recycled Concrete (RC), Crushed red brick (REB) and Crushed ceramic (CER.) The percentages of replacements are: $25 \%, 50 \%, 75 \%$ and 100\%, for each type of aggregate. The results show that the increase of the amount of recycled aggregates decreases the strength properties of SSC and effect on workability of SSC also the result show a reduction in oven dry density. The combination of different type of recycled aggregate shows a reduction in SSC strength. The use of fibers shows better performance of SSC compared to combination aggregate mix without fiber but reduce the workability of SCC. However, the fiber content of $1.0 \%$ shows the best result of the mechanical properties, whereas, fiber content up to $1.5 \%$ affects negatively on concrete properties. The use of hybrid fiber also increases the strength properties of concrete.

Key words: recycled concrete, crushed red brick, ceramic aggregate, ceramic powder, SCC

\section{INTRODUCTION}

Conventional concrete technology requires mechanical vibration for placing concrete, which is time- and energy-consuming, noisy and often dangerous. In order to overcome these issues, self-compacting concrete (SCC) is developed, However, facing growing demands related with a sustainable development, technology of self-compacting concrete becoming questionable for the reason of its relatively high content of cement which can cause high heat of hydration danger of quick setting, also that cause an increased value of carbon footprint also as we mention before there is huge quantities of construction and demolition waste which represent a real challenge to environmentalist so recycling this waste can effectively contribute to manage these waste Also there another problem related to the concrete which is brittleness nature of concrete the using of the fiber will help to overcome this problem because of the Abundance of raw materials the using of conventional building materials is more traditional so hope this research carried out and the using of recycled material become more acceptance.[1-6]

This study aimed to design self-compacting concrete reinforced with hybrid fiber (recycled plastic and sisal fiber) and study the effect of using different recycled material as partial replacement of cement and to investigate the effect of using different recycled aggregate on the behavior of concrete of both fresh and hardened properties.

\section{EXPERIMENTAL PROGRAM}

This section covers the materials used and the tests done.

\section{Materials used}

Cement: Ordinary Portland cement (OPC) Type I used in this study has been manufactured from Badoosh factory. Its physical characteristics and chemical compositions are illustrated in Tables 1 and 2, respectively.

Fine aggregate: The sand used in this study was the natural river sand from Kanhash region in Mosul city with specific gravity of 2.63 .

Table 1: Physical characteristics of ordinary Portland cement

\begin{tabular}{|c|c|c|}
\hline Test & $\begin{array}{c}\text { Produced } \\
\text { cement }\end{array}$ & ASTM C150 [7] \\
\hline $\begin{array}{l}\text { Initial setting time } \\
\text { (minute) }\end{array}$ & 143 & $\min 45$ \\
\hline $\begin{array}{c}\text { Final setting time } \\
\text { (minute) }\end{array}$ & 175.5 & $\max 600$ \\
\hline $\begin{array}{c}\text { Fineness } \\
\text { Blain }\left(\mathrm{cm}^{2} / \mathrm{g}\right)\end{array}$ & 3398 & more than 2300 \\
\hline $\begin{array}{c}\text { Compressive strength } \\
3 \text { days, } \mathrm{N} / \mathrm{mm}^{2} \\
7 \text { days, } \mathrm{N} / \mathrm{mm}^{2}\end{array}$ & $\begin{array}{c}31.64 \\
39.3\end{array}$ & $\begin{array}{l}\geq 12 \\
\geq 19\end{array}$ \\
\hline
\end{tabular}

Coarse aggregate (Gravel): The washed rounded aggregate of $12.5 \mathrm{~mm}$ maximum size was used, the specific gravity and absorption are 2.68 and $0.4 \%$, respectively. Tap water: Normal tap water has been used for concrete mixtures. 
Table 2: Chemical composition of ordinary Portland cement

\begin{tabular}{|c|c|c|}
\hline Constituent & Content Percent (\%) & ASTM C 150 [7] \\
\hline $\mathrm{CaO}$ & 62.5 & - \\
\hline $\mathrm{SiO}_{2}$ & 20.91 & - \\
\hline $\mathrm{Al}_{2} \mathrm{O}_{2}$ & 5.96 & - \\
\hline $\mathrm{MgO}$ & 3.8 & $\geq 5.0 \%$ \\
\hline $\mathrm{Fe}_{2} \mathrm{O}_{2}$ & 2.53 & - \\
\hline $\mathrm{SO}_{2}$ & 2.32 & $\geq 2.8 \%$ \\
\hline $\mathrm{L} . \mathrm{O} . \mathrm{I}$ & 1.45 & $\geq 4.0 \%$ \\
\hline $\mathrm{C}_{3} \mathrm{~S}$ & 33.37 & - \\
\hline $\mathrm{C}_{2} \mathrm{~S}$ & 35.92 & - \\
\hline $\mathrm{C}_{3} \mathrm{~A}$ & 11.5 & - \\
\hline $\mathrm{C}_{4} \mathrm{AF}$ & 7.7 & - \\
\hline
\end{tabular}

Super plasticizer: High-range water-reducing (HRWR) admixture, super plasticizer from (Sika Visco Creteß-5930), was used to confirm the desired workability of mixes.

Recycled concrete aggregate (RC): Recycled concrete was collected from the demolition of ruined buildings in city with specific gravity of 2.22 and absorption of 5.12 . Such aggregate has been crushed to appropriate size and the maximum aggregate size is $12.5 \mathrm{~mm}$.

Waste clay brick aggregate: A waste of clay bricks has been crushed to an appropriate size with specific gravity of 1.90 and absorption of $3.8 \%$ has been used in this study.

Crushed ceramic aggregate: Crushed ceramic aggregate was collected from ceramic storages in Mosul city. It has a specific gravity of 2.1 and absorption of $0.81 \%$.

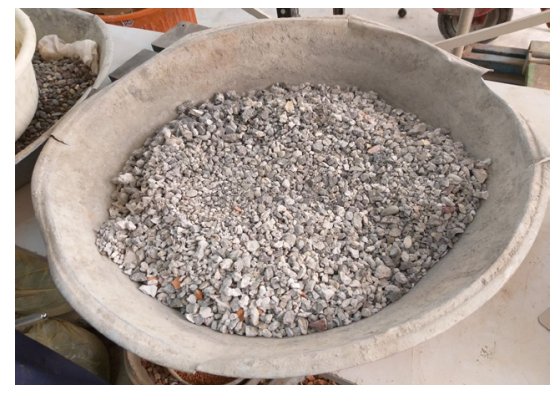

Figure 1: Recycled concrete aggregate

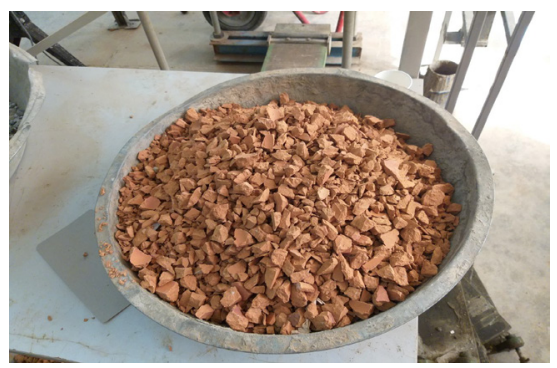

Figure 2: Clay brick aggregate
Ceramic waste powder (CWP): It was collected from damaged ceramic materials from the ceramic storages in Mosul city, then it has been crushed and grinded then sieved to be passing through sieve No.200.

Glass powder: The glass from residual broken glass in Mosul city was crushed and grinded then sieved to be passed through sieve No 200.

Fly ash: Fly ash was brought from DCP company in Erbil city. It conforms to ASTM C618 Class F [8]. The characteristics of such materials are shown in Table 3 to show the characteristics of it.

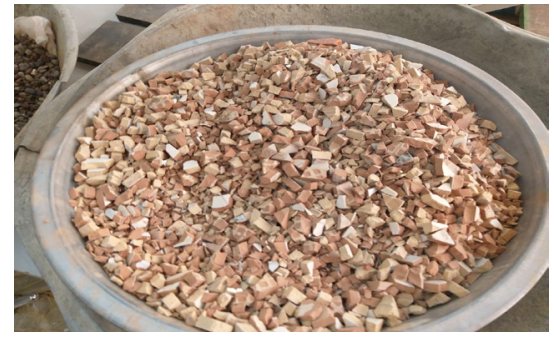

Figure 3: crushed ceramic aggregate

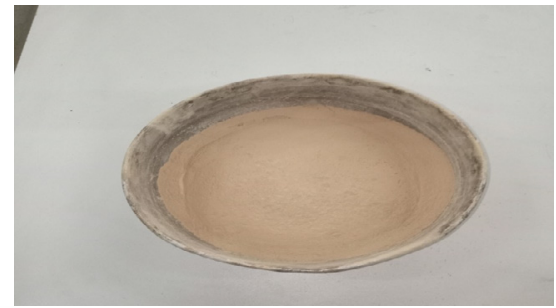

Figure 4: Waste ceramic powder

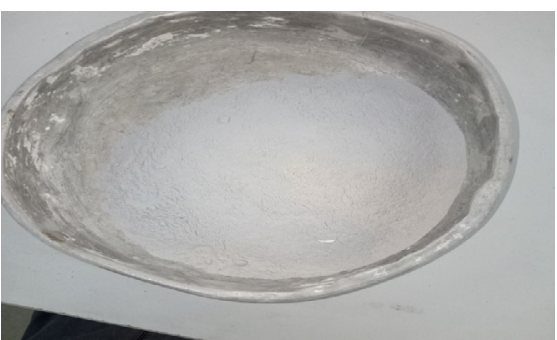

Figure 5: Glass powder

Table 3: Characteristics of fly ash

\begin{tabular}{|c|c|}
\hline Appearance & Pale grey fine powder \\
\hline Relative Density & 2.12 \\
\hline PH in water & $7 \_12$ \\
\hline Theoretical surface area & $200 \_700$ \\
\hline Loss on Ignition \% & 5 \\
\hline $\mathrm{SO}_{3} \%$ & 3.0 \\
\hline Moisture Content \% & 3 \\
\hline Fineness (Retained on $45 \mu$ ) & $5.0 \_25$ \\
\hline Sum of Oxide (Al+Si+Fe) & 70 \\
\hline Chloride $\%$ & 0.1 \\
\hline
\end{tabular}

Istraživanja i projektovanja za privredu ISSN 1451-4117 Journal of Applied Engineering Science Vol. 19, No. 1, 2021 


\section{Fiber}

Sisal fiber: Natural sisal fiber was used with length of 20 $\mathrm{mm}$ and aspect ratio of 40 .

Recycled plastic fiber: Recycled plastic from PVC factory where chopped into length of $20 \mathrm{~mm}$ and diameter of $2 \mathrm{~mm}$ and aspect ratio of 10 .

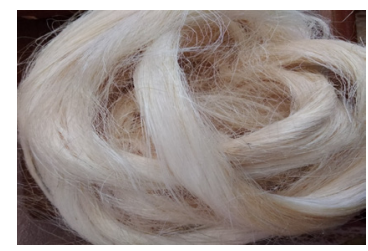

Figure 6: Sisal fiber

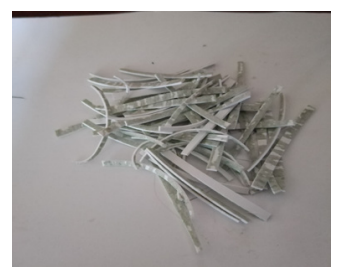

Figure 7: Plastic fiber

\section{Mix proportion}

The proper ties of SCC are affected by the material properties; the mix proportion was 1:1.60:1.40. The water to binder is 0.38 with total cementitious materials of $528 \mathrm{~kg} / \mathrm{m}^{3}$. The cement content is $368 \mathrm{~kg}$, fly ash is 52.8 , ceramic waste powder (CWP) is $63.6 \mathrm{~kg}$, and glass powder (GP) is 42.2 $\mathrm{kg}$. The designation of the mixes and mix proportions are depicted in Tables $4 \& 5$. The SCC mixes reinforced with fibers are listed in Table 6.

Mixing procedure: mixing procedure for SCC is more sensitive to the time comparing to the conventional concrete, the following procedure where performed to obtain a SSC:

1. Fine and coarse aggregates are loading and mixing at the beginning for 1 minute

2. Cement and filler are added and mixed for 1 minute.

3. A half of mixing water in addition to Sika visco-crete 5930 have been added and mixed for 2 minutes

4. The residual water and fibers are carefully added (to avoid balling) an mixed with 3 minutes.

Casting and curing: After finishing the mix procedure the test of fresh concrete were done to conduct Slump and flow time $\mathrm{v}$-funnel L-box tests.

Table 4: Details of SCC mixes

\begin{tabular}{|c|c|c|}
\hline Mix name & Details & Remarks \\
\hline Ro & Reference mix with no cementitious materials & ------ \\
\hline R1 & Reference mix with $30 \%$ cementitious materials & $\begin{array}{c}\text { The percentages of each of fly ash, glass powder } \\
\text { and ceramic powder are determined depending on } \\
\text { mortar trial mixes to get the optimum percentages } \\
\text { of combination }\end{array}$ \\
\hline $\mathrm{RC} 25$ & $\begin{array}{l}25 \% \text { of coarse aggregate has volumetrically } \\
\text { been replaced by recycled concrete. }\end{array}$ & $\begin{array}{c}\text { Same cementitious materials combination as R1 } \\
\text { have been considered }\end{array}$ \\
\hline $\mathrm{RC} 50$ & $\begin{array}{l}50 \% \text { of coarse aggregate has volumetrically } \\
\text { been replaced by recycled concrete. }\end{array}$ & $\begin{array}{c}\text { Same cementitious materials combination as R1 } \\
\text { have been considered }\end{array}$ \\
\hline $\mathrm{RC75}$ & $\begin{array}{l}75 \% \text { of coarse aggregate has volumetrically } \\
\text { been replaced by recycled concrete. }\end{array}$ & $\begin{array}{c}\text { Same cementitious materials combination as R1 } \\
\text { have been considered }\end{array}$ \\
\hline RC100 & $\begin{array}{l}100 \% \text { of coarse aggregate has volumetrically } \\
\text { been replaced by recycled concrete. }\end{array}$ & $\begin{array}{c}\text { Same cementitious materials combination as R1 } \\
\text { have been considered }\end{array}$ \\
\hline REB25 & $\begin{array}{l}25 \% \text { of coarse aggregate has volumetrically } \\
\text { been replaced by red brick aggregate. }\end{array}$ & $\begin{array}{c}\text { Same cementitious materials combination as R1 } \\
\text { have been considered }\end{array}$ \\
\hline REB50 & $\begin{array}{l}50 \% \text { of coarse aggregate has volumetrically } \\
\text { been replaced by red brick aggregate. }\end{array}$ & $\begin{array}{c}\text { Same cementitious materials combination as R1 } \\
\text { have been considered }\end{array}$ \\
\hline REB75 & $\begin{array}{l}75 \% \text { of coarse aggregate has volumetrically } \\
\text { been replaced by red brick aggregate. }\end{array}$ & $\begin{array}{c}\text { Same cementitious materials combination as R1 } \\
\text { have been considered }\end{array}$ \\
\hline REB100 & $\begin{array}{c}100 \% \text { of coarse aggregate has volumetrically } \\
\text { been replaced by red brick aggregate. }\end{array}$ & $\begin{array}{c}\text { Same cementitious materials combination as R1 } \\
\text { have been considered }\end{array}$ \\
\hline CER25 & $\begin{array}{l}25 \% \text { of coarse aggregate has volumetrically } \\
\text { been replaced by crushed ceramic aggregate }\end{array}$ & $\begin{array}{c}\text { Same cementitious materials combination as R1 } \\
\text { have been considered }\end{array}$ \\
\hline CER50 & $\begin{array}{l}50 \% \text { of coarse aggregate has volumetrically } \\
\text { been replaced by crushed ceramic aggregate }\end{array}$ & $\begin{array}{c}\text { Same cementitious materials combination as R1 } \\
\text { have been considered }\end{array}$ \\
\hline CER75 & $\begin{array}{l}75 \% \text { of coarse aggregate has volumetrically } \\
\text { been replaced by crushed ceramic aggregate }\end{array}$ & $\begin{array}{c}\text { Same cementitious materials combination as R1 } \\
\text { have been considered }\end{array}$ \\
\hline CER100 & $\begin{array}{l}100 \% \text { of coarse aggregate has volumetrically } \\
\text { been replaced by crushed ceramic aggregate }\end{array}$ & $\begin{array}{c}\text { Same cementitious materials combination as R1 } \\
\text { have been considered }\end{array}$ \\
\hline
\end{tabular}


Table 5: Mix Proportions of SCC with recycled aggregate

\begin{tabular}{|c|c|c|c|c|c|c|c|c|}
\hline MIXES & $\begin{array}{c}\text { Cement } \\
\mathrm{Kg} / \mathrm{m}^{3}\end{array}$ & Fly ash & $\begin{array}{c}\text { Ceramic } \\
\text { waste } \\
\text { powder } \\
\text { (CWP) }\end{array}$ & $\begin{array}{c}\text { Glass } \\
\text { powder } \\
(\mathrm{GP})\end{array}$ & $\begin{array}{c}\text { Sand } \\
\mathrm{Kg} / \mathrm{m}^{3}\end{array}$ & $\begin{array}{c}\text { Coarse agg. } \\
\text { (gravel) }\left(\mathrm{kg} / \mathrm{m}^{3}\right)\end{array}$ & $\begin{array}{c}\text { Volumetric replacement of } \\
\text { coarse agg. }\end{array}$ & Sp.\% \\
\hline RO & 528 & --- & --- & --- & 844 & 739 & 0 & 0.8 \\
\hline R1 & 368 & 52.8 & 63.6 & 42.2 & 844 & 739 & 0 & 0.8 \\
\hline RC25 & 368 & 52.8 & 63.6 & 42.2 & 844 & 554 & $50 \%$ & 0.85 \\
\hline RC50 & 368 & 52.8 & 63.6 & 42.2 & 844 & 370 & $75 \%$ & 0.85 \\
\hline RC75 & 368 & 52.8 & 63.6 & 42.2 & 844 & 185 & $100 \%$ & 0.88 \\
\hline RC100 & 368 & 52.8 & 63.6 & 42.2 & 844 & 0 & $25 \%$ & 1.0 \\
\hline REB25 & 368 & 52.8 & 63.6 & 42.2 & 844 & 554 & $50 \%$ & 1.2 \\
\hline REB50 & 368 & 52.8 & 63.6 & 42.2 & 844 & 370 & $15 \%$ & 1.25 \\
\hline REB75 & 368 & 52.8 & 63.6 & 42.2 & 844 & 185 & $25 \%$ & 1.35 \\
\hline REB100 & 368 & 52.8 & 63.6 & 42.2 & 844 & 0 & $50 \%$ & 0.9 \\
\hline CER25 & 368 & 52.8 & 63.6 & 42.2 & 844 & 554 & 374 & 0.95 \\
\hline CER50 & 368 & 52.8 & 63.6 & 42.2 & 844 & 370 & $100 \%$ & 1.0 \\
\hline CER75 & 368 & 52.8 & 63.6 & 42.2 & 844 & 185 & 0 & 1.2 \\
\hline CER100 & 368 & 52.8 & 63.6 & 42.2 & 844 & 0 & $100 \%$ & \\
\hline
\end{tabular}

The molds were used steel and plastic mold were lubricated and the specimens were cast only in one layer without any compaction. All specimens were kept in laboratory for $(24 \pm 2)$ hours then demolded and immersed in water until the specific testing time.

Test procedure: The tested fresh properties of SSC includes methods used for Filling ability, Passing ability and Segregation resistance (slump flow, L-box and V -funnel tests), respectively.

Whereas, the hardened SCC tests includes compressive strength test which was carried out on $100 \times 100 \times 100 \mathrm{~mm}$ cube specimens based on BS 1881: part 5 [9]. The average of three specimens was recorded and considered for each age test (7, 28 and 90 days).

The splitting tensile strength was performed in accordance with ASTM C496 [10] and conducted on cylinders of $100 * 200 \mathrm{~mm}$. The average of three test specimens has been taken at 7, 28 and 90 days.

Also, the flexural strength test was done according to ASTM C78 [11]. The flexural strength was carried on $100 * 100 * 400 \mathrm{~mm}$ prisms. The flexural value was taken as the average value of three specimens at 7,28 and 90 days. The dry density concrete for SCC in a hardened state at age 28 days was carried out in accordance with ASTM C 642 [12]. Lastly, the Ultrasonic Pulse Velocity (UPV) Test was performed on specimens at age of 28 day. The test was carried out in accordance with ASTM C597 [13]

\section{RESULTS AND DISCUSSIONS}

This section deals with the analysis of the results which were obtained after testing all the specimens and their dis-

Table 6: Mix proportions of SCC with recycled aggregate with fibers

\begin{tabular}{|c|c|c|c|c|c|c|c|}
\hline $\mathrm{MIX}$ & Sisal & Plastic & $\mathrm{NA} \mathrm{Kg} / \mathrm{m}^{3}$ & $\mathrm{RC} \mathrm{Kg} / \mathrm{m}^{3}$ & $\mathrm{CER} \mathrm{Kg} / \mathrm{m}^{3}$ & $\mathrm{REB} \mathrm{kg} / \mathrm{m}^{3}$ & $\mathrm{SP} \%$ \\
\hline F0 & ---- & ---- & 293 & 162.7 & 152 & 131 & 1.0 \\
\hline F1 & 0.5 & ---- & 293 & 162.7 & 152 & 131 & 1.0 \\
\hline F2 & 1.0 & ---- & 293 & 162.7 & 152 & 131 & 1.0 \\
\hline F3 & 1.5 & ---- & 293 & 162.7 & 152 & 131 & 1.2 \\
\hline F4 & ---- & 0.5 & 293 & 162.7 & 152 & 131 & 1.0 \\
\hline F5 & ---- & 1.0 & 293 & 162.7 & 152 & 131 & 1.0 \\
\hline F6 & ---- & 1.5 & 293 & 162.7 & 152 & 131 & 1.0 \\
\hline F7 & 0.5 & 0.5 & 293 & 162.7 & 152 & 131 & 1.5 \\
\hline F8 & 1.0 & 1.0 & 293 & 162.7 & 152 & 131 & 1.6 \\
\hline F9 & 0.5 & 1.0 & 293 & 162.7 & 152 & 131 & 1.5 \\
\hline F10 & 1.0 & 0.5 & 293 & 162.7 & 152 & 131 & 1.5 \\
\hline
\end{tabular}


cussion. The results show the effect of different recycled aggregate and different type of fibers and hybrid fibers on both fresh and hardened properties of SCC mixes.

Fresh properties: The fresh properties include workability tests which are: slump test, V-funnel and L-box. Table 7 shows the results of different SCC mixes prepared by various recycled aggregates. From this Table, it can be noticed that the slump value ranges from 630 $\mathrm{mm}$ to $733 \mathrm{~mm}$. While the $\mathrm{T} 500$ ranges from 2.57 to 4.0 $\mathrm{sec}$, the $\mathrm{v}$-funnel ranging from $7.5 \mathrm{sec}$ to $11 \mathrm{sec}$ and L-box varies from 0.72 to 0.9 . From the results, it can be observed that amount of recycled aggregate would reduce the workability. This may return to the shape of this aggregate and the reduction of free water in SSC which is the main dominant of the recycled aggregate. The lowest value of flow has been obtained when the normal aggregate was completely replaced by crushed ceramic. Whereas, the crushed clay bricks aggregate show the best value among the recycled aggregate. Adding CWP, GP, Fly ash show a slight decrease in flow diameter and this may be related to the SSC become more viscous. The Table 8 shows the test results of workability for the fiber mixes of sisal fiber, plastic fiber and hybrid fiber. It can be seen that the increase in $\mathrm{Vf}$ of fiber reduces the slump value from $681 \mathrm{~mm}$ to $640 \mathrm{~mm}$ for the mixes SF1 and SF2, while the v-funnel result ranges from 11 to 13 sec and the L-box ranging from 0.77 to 0 .

\section{Hardened properties}

\section{Compressive strength}

Table 9 shows the compressive strength of mixes of recycled concrete aggregate in addition to the reference value. From such Table, it can be observed that the use of $\mathrm{RC}$ reduces the compressive strength of SCC and this

Table 7: Workability tests for SCC mixes prepared by various recycled aggregates

\begin{tabular}{|c|c|c|c|c|}
\hline Mixes & T500(sec) & Slump(mm) & $\begin{array}{c}\text { L-box } \\
\text { h2/h1 }\end{array}$ & $\begin{array}{c}\text { V-funnel } \\
\text { (sec) }\end{array}$ \\
\hline R0 & 2.57 & 733 & 0.72 & 7.5 \\
\hline R1 & 2.63 & 712 & 0.75 & 8.0 \\
\hline RC25 & 2.70 & 690 & 0.79 & 8.62 \\
\hline RC50 & 2.71 & 675 & 0.83 & 9.0 \\
\hline RC75 & 2.75 & 655 & 0.86 & 10 \\
\hline RC100 & 2.78 & 650 & 0.88 & 10.5 \\
\hline REB 25 & 2.88 & 705 & 0.77 & 9 \\
\hline REB50 & 2.96 & 695 & 0.80 & 9.5 \\
\hline REB75 & 3.11 & 690 & 0.80 & 9.0 \\
\hline REB100 & 3.5 & 683 & 0.82 & 9.5 \\
\hline CER25 & 2.95 & 680 & 0.81 & 10 \\
\hline CER50 & 3.25 & 677 & 0.83 & 10.5 \\
\hline CER75 & 3.5 & 650 & 0.86 & 10.8 \\
\hline CER 100 & 4.0 & 630 & 0.9 & 11.0 \\
\hline
\end{tabular}

Table 8: Workability test of fiber mixes

\begin{tabular}{|c|c|c|c|c|}
\hline Mixes & T500 (sec) & Slump (mm) & $\begin{array}{c}\text { L-box } \\
\text { h2/h1 }\end{array}$ & $\begin{array}{c}\text { V-funnel } \\
\text { sec }\end{array}$ \\
\hline F0 & & & & \\
\hline F1 & 3.15 & 681 & 0.75 & 11 \\
\hline F2 & 3.5 & 677 & 0.78 & 12 \\
\hline F3 & 3.7 & 665 & 0.83 & 12.5 \\
\hline F4 & 3.5 & 675 & 0.77 & 12 \\
\hline F5 & 4.0 & 655 & 0.8 & 11.5 \\
\hline F6 & 4.1 & 652 & 0.85 & 11.8 \\
\hline F7 & 4.3 & 668 & 0.86 & 12.0 \\
\hline F8 & 5.2 & 640 & 0.98 & 13 \\
\hline F9 & 4.7 & 645 & 093 & 12.3 \\
\hline F10 & 4.53 & 640 & 0.91 & 11.5 \\
\hline
\end{tabular}

may be due to the low property of RC aggregate compared with normal aggregate. Also, it can be noticed that the increase of the crushed clay brick amount, reduces the compressive strength at all age of concrete. This reduction is related to the reduction in adhesive strength between surface of particle of crushed clay brick and cement paste also may related to the difference of shape and size between natural aggregate also the reduction may also related to low strength properties of clay brick [14]. The incorporating of ceramic aggregate causes a reduction in compressive strength and this reduction may attributed to the weak bond between CER aggregate and cement paste and the shape of CER aggregate make a continues path of porosity which led to un dense concrete the reduction was at all age of concrete [15].

Table 9: Compressive strength for SCC with recycled aggregate

\begin{tabular}{|c|c|c|c|}
\hline MIXES & 7 Days & 28 Days & 90 Days \\
\hline R0 & 36.74 & 43.505 & 50.02 \\
\hline R1 & 34.2 & 44.74 & 53.52 \\
\hline RC25 & 32.9 & 41.70 & 51.15 \\
\hline RC50 & 31.5 & 40.8 & 49.3 \\
\hline RC75 & 30.1 & 37.9 & 47.8 \\
\hline RC100 & 27.73 & 35.29 & 45.35 \\
\hline REB 25 & 33.71 & 40.95 & 50.86 \\
\hline REB 50 & 30.2 & 39.167 & 48.8 \\
\hline REB 75 & 29.22 & 38.46 & 47.32 \\
\hline REB 100 & 27.73 & 36.45 & 45.02 \\
\hline CER25 & 28.20 & 33.701 & 41.981 \\
\hline CER50 & 26.77 & 32.31 & 40.08 \\
\hline CER75 & 25.39 & 39.93 & 44.18 \\
\hline CER100 & 23.16 & 28.7 & 38.905 \\
\hline
\end{tabular}


Table 10: Compressive strength for SCC reinforced with fibers

\begin{tabular}{|c|c|c|c|}
\hline MIXES & 7 Days & 28 Days & 90 Days \\
\hline F0 & 28.29 & 37.34 & 44.285 \\
\hline F1 & 27.33 & 36.51 & 43.49 \\
\hline F2 & 26.23 & 35.38 & 42.89 \\
\hline F3 & 24.88 & 33.88 & 41.23 \\
\hline F4 & 30.34 & 39.45 & 47.13 \\
\hline F5 & 30.87 & 40.05 & 48.13 \\
\hline F6 & 29.88 & 38.98 & 46.56 \\
\hline F7 & 31.44 & 42.10 & 46.58 \\
\hline F8 & 30.77 & 40.45 & 44.88 \\
\hline F9 & 29.73 & 38.12 & 42.15 \\
\hline F10 & 30.25 & 39.77 & 44.56 \\
\hline
\end{tabular}

\section{Splitting tensile strength}

From Table 10, it can be seen that the recycled concrete aggregate increase, may reduce the splitting tensile strength of SCC. The reduction is related to low strength properties of recycled aggregate and that super poses with most results of global research. From fig 4.16 and table 4.16 we find that the adding sisal fiber increase the splitting tensile strength the increasing was up to $1.0 \%$ while increasing fiber to $1.5 \%$ show slight reduction the increasing was $(2 \%$, $1 \%, 7 \%$ ) for vf of 0.5 at the ages of $7,28.90$ day while vf of $1.0 \%$ caused increasing of $(22.1 \%, 11.5 \%, 9)$ at ages of 7 , 28,90 day respectively. It can also be found that the addition of plastic fiber enhances the splitting tensile strength of SCC. Vf of $1.0 \%$ caused an increase by about $1.7 \%$. While $\mathrm{Vf}$ of 1.5 caused an increase by about $14.9 \%$ at age of 90 day. It can also be noticed that the use of $0.5 \mathrm{~S}+0.5 \mathrm{P}$ caus-

Table 11: Splitting tensile strength for SCC with recycled aggregate

\begin{tabular}{|c|c|c|c|}
\hline MIXES & 7 Days & 28 Days & 90 Days \\
\hline R0 & 6.413 & 6.577 & 6.63 \\
\hline R1 & 6.505 & 6.72 & 6.78 \\
\hline RC25 & 5.53 & 5.67 & 5.95 \\
\hline RC50 & 5.41 & 5.45 & 5.62 \\
\hline RC75 & 4.65 & 4.68 & 5.05 \\
\hline RC100 & 4.48 & 4.51 & 4.8 \\
\hline REB 25 & 5.89 & 6.03 & 6.15 \\
\hline REB 50 & 5.68 & 5.33 & 5.55 \\
\hline REB 75 & 5.21 & 5.25 & 5.41 \\
\hline REB 100 & 4.84 & 5.15 & 5.27 \\
\hline CER25 & 5.91 & 6.11 & 6.21 \\
\hline CER50 & 5.53 & 5.85 & 5.92 \\
\hline CER75 & 4.95 & 5.20 & 5.25 \\
\hline CER100 & 4.70 & 4.73 & 4.85 \\
\hline
\end{tabular}

Table 12: Splitting tensile strength for SCC reinforced with fibers

\begin{tabular}{|c|c|c|c|}
\hline MIXES & 7 Days & 28 Days & 90 Days \\
\hline F0 & 2.25 & 2.79 & 3.3 \\
\hline F1 & 2.3 & 2.81 & 3.56 \\
\hline F2 & 2.89 & 3.15 & 3.67 \\
\hline F3 & 2.71 & 2.98 & 3.25 \\
\hline F4 & 2.77 & 3.1 & 3.25 \\
\hline F5 & 3.17 & 3.33 & 3.42 \\
\hline F6 & 3.35 & 3.66 & 3.88 \\
\hline F7 & 2.78 & 3.16 & 3.53 \\
\hline F8 & 2.56 & 2.99 & 3.36 \\
\hline F9 & 2.54 & 2.86 & 3.23 \\
\hline F10 & 2.87 & 3.11 & 3.88 \\
\hline
\end{tabular}

es an increase by about $6 \%$. Whereas, the use of $1 \mathrm{P}+1 \mathrm{~S}$ causes an increase by about $1.7 \%$ using $0.5 s+1 p$ causes a reduction by about $2 \%$ while using $0.5 p+1 S$ causes an increase by about $4 \%$.

\section{Flexural strength}

From figure (4.7) and table (4.8) we found adding of SCM show slight increment in flexural value with $(1.4 \%, 2.1 \%$, $1.7 \%)$ at the ages $(7,28,90)$ day respectively while incorporating the RC aggregate caused in flexural reduction the value of reduction increased with increasing amount of RC content the reduction was $(13.7 \%, 7.9 \%)$ and $10 \%$ at ages of $(7,28,90)$ respectively for RC25 while for RC50 the reduction was $15.6 \%, 17 \%, 15.2 \%$ at ages of $(7,28,90$,days) for RC75 the reduction was $(27 \%, 28,8 \%, 23 \%)$ for RC100 the reduction was $(30.4 \%$,

Table 13: Flexural strength for SCC with recycled aggregate

\begin{tabular}{|c|c|c|c|}
\hline MIXES & 7 Days & 28 Days & 90 Days \\
\hline R0 & 6.413 & 6.577 & 6.63 \\
\hline R1 & 6.505 & 6.72 & 6.78 \\
\hline RC25 & 5.53 & 5.67 & 5.95 \\
\hline RC50 & 5.41 & 5.45 & 5.62 \\
\hline RC75 & 4.65 & 4.68 & 5.05 \\
\hline RC100 & 4.48 & 4.51 & 4.8 \\
\hline REB 25 & 5.89 & 6.03 & 6.15 \\
\hline REB 50 & 5.68 & 5.33 & 5.55 \\
\hline REB 75 & 5.21 & 5.25 & 5.41 \\
\hline REB 100 & 4.84 & 5.15 & 5.27 \\
\hline CER25 & 5.91 & 6.11 & 6.21 \\
\hline CER50 & 5.53 & 5.85 & 5.92 \\
\hline CER75 & 4.95 & 5.20 & 5.25 \\
\hline CER100 & 4.70 & 4.73 & 4.85 \\
\hline
\end{tabular}


Table 14: Flexural strength for SCC reinforced with fibers

\begin{tabular}{|c|c|c|c|}
\hline MIXES & 7 Days & 28 Days & 90 Days \\
\hline F0 & 4.15 & 4.38 & 4.75 \\
\hline F1 & 4.16 & 4.39 & 5.12 \\
\hline F2 & 4.2 & 4.45 & 5.20 \\
\hline F3 & 4.05 & 4.27 & 4.92 \\
\hline F4 & 4.25 & 4.55 & 4.67 \\
\hline F5 & 4.33 & 4.50 & 4.71 \\
\hline F6 & 4.22 & 4.45 & 4.66 \\
\hline F7 & 4.25 & 4.37 & 4.78 \\
\hline F8 & 4.56 & 4.96 & 5.23 \\
\hline F9 & 4.43 & 4.89 & 5.13 \\
\hline F10 & 4.61 & 5.11 & 5.56 \\
\hline
\end{tabular}

$30.1 \%, 27.6 \%)$ the low strength value may return to the low strength properties of RC comparing to normal aggregate. The CER aggregate mixes show reduction in flexural strength the reduction was $7.8 \%, 6.8 \%, 7,2 \%$ at ages of $7,28,90$ day for CER25 for CER50 the reduction was $13.7 \%, 11.7 \%$, and for CER75 $22.8 \%, 20.6 \%$, $23.8 \%$ for CER 100 the $26.7 \%$, 28.8\%, 26,8\%. From Table (4.10) and Figure (4.9) the (REB mixes) show that reduction in flexural strength value for REB25 the reduction was $(8.1 \%, 8.7 \%, 7.2 \%)$ for REB50, the reduction was $(11.4 \%, 19 \%, 16.2 \%)$. For REB75 the reduction was $(18.7 \%, 19.9, \%, 20.5)$ for REB100 the reduction was $(24.5 \%, 21.4 \%, 20.5 \%)$ at the ages of $7,28,90$ day respectively. From figure 4.20 and table 4.20 we find that adding sisal fiber mixes increasing the flexural strength the increasing at vf of $0.5 \%$ was $4 \%$ and for vf of 1.0 the increasing was $4.8 \%$ while $1.5 \%$ vf show slight reduction at the age of 90 day. Table 4.21 and figure 4.21 we observed that adding 1.0 of plastic fiber cause slight decreasing in flexural value the reduction was $1.6 \%$ for $0.5 \%$ and 1.8 for $1.5 \%$ at age of 90 day. From figure 4.22 and table 4.22 we find that using $0.5 s+0.5 p$ cause increasing about $0.6 \%$ and using $1 S+1 p$ cause increasing about $9 \%$ while using $0.5 \mathrm{~S}+1.0 \mathrm{P}$ cause increasing about $7 \%$ while using $0.5 \mathrm{P}+1.0 \mathrm{~S}$ cause increasing about $13 \%$.

\section{Density and ultra pulse velocity (UPV)}

From Table 15, it can be found that the UPV values depend on the density. Hence, the increase in UPV values was comparable with the increase in density values for SCC prepared from recycled aggregate with or without fibers.

\section{CONCLUSIONS}

Some conclusions are revealed for this study which deals with the production of Self Compacting Concrete (SCC) as follows:

1. There is ability to replace normal aggregate with recycled aggregate (recycled concrete aggregate,
Table 15: Density and UPV TEST

\begin{tabular}{|c|c|c|}
\hline MIXES & Density $\left(\mathrm{Kg} / \mathrm{m}^{3}\right)$ & UPV Test $(\mathrm{km} / \mathrm{sec})$ \\
\hline RO & 2340 & 5.5 \\
\hline R1 & 2331 & 5.35 \\
\hline RC25 & 2310 & 5.2 \\
\hline RC50 & 2300 & 5.12 \\
\hline RC75 & 2285 & 5.005 \\
\hline RC100 & 2280 & 4.95 \\
\hline REB25 & 2284 & 4.93 \\
\hline REB50 & 2196 & 4.88 \\
\hline REB75 & 2095 & 4.5 \\
\hline REB100 & 1995 & 4.0 \\
\hline CER25 & 2285 & 4.25 \\
\hline CER50 & 2277 & 4.11 \\
\hline CER75 & 2270 & 4.1 \\
\hline CER100 & 2265 & 3.99 \\
\hline F0 & 2210 & 3.75 \\
\hline F1 & 2213 & 3.78 \\
\hline F2 & 2210 & 3.72 \\
\hline F3 & 2215 & 3.67 \\
\hline F4 & 2215 & 3.55 \\
\hline F5 & 2208 & 3.34 \\
\hline F6 & 2215 & 3.26 \\
\hline F7 & 2216 & 3.41 \\
\hline F8 & 2225 & 3.21 \\
\hline F9 & 2212 & 3.33 \\
\hline F10 & 2213 & 3.78 \\
\hline
\end{tabular}

crushed ceramic, crushed clay brick) up to $25 \%$ without significant influence of concrete properties.

2. The crushed ceramic aggregate gives the lowest strength values compared with other types of aggregate.

3. The increase in recycled aggregate reduces the workability, oven dry density and strength.

4. Sisal fiber can be used to improve splitting and flexural strength. However, the plastic fiber can be used up to $1 \%$ to give best result and the hybrization of two type fiber improves strength properties.

\section{ACKNOWLEDGEMENT}

The work described in this paper has been conducted in the laboratory of Technical engineering college of Mosul.

\section{REFERENCES}

1. Limbachiya, M.C., Leelawat, T. and Dhir, R. K (2000) "Use of recycled concrete aggregate in high-strength concrete" Materials and Structures/Materiaux et Constructions, Vol. 33, pp. 574-580. https://doi. org/10.1007/BF02480538 
2. Kou, S. C., and Poon, C. S (2009)" Properties of self-compacting concrete prepared with coarse and fine recycled concrete aggregates. Cement and Concrete composites, 31(9), pp.622-627. https://doi. org/10.1016/j.cemconcomp.2009.06.005

3. Adamson, M, Razmjoo, A. and Poursaee, A (2015) "Durability of concrete incorporating crushed brick as coarse aggregate" Constr. Build. Mater. 94,30 Sep., pp.426-432. https://doi.org/10.1016/j.conbuildmat.2015.07.056

4. Wang, H. and Zhang, N.(2016) "Assessment of treated recycled concrete aggregates on the properties of recycled-aggregate-self-compacting concrete" J. Harbin. Inst. Tech. 48 ,pp.150-156.

5. Amir, K (2013) "Fracture Toughness of Hybrid Fibers Reinforced Self-Compacting Concrete" Department of Civil Engineering The University of British Columbia Vancouver, Canada March 10.

6. Choi, H.S., Choi, H., Lim, M., Inoue, M., Kitagaki, R. and Noguchi, T. (2016) "Evaluation on the mechanical performance of low-quality recycled aggregate through interface enhancement between cement matrix and coarse aggregate by surface modification technology, IJCSM 10, pp.87-97. https://doi. org/10.1007/s40069-015-0124-5

7. ASTM C150 "Standard Specification for Portland Cement", American Society Tests of Material, 2020, C1621 "Annual book of ASTM Standard, Volume 04.02"ASTM international, West Conshohocken, PA, www.astm.org.

8. ASTM C618 "Standard Specification for Coal Fly Ash and Raw or Calcined Natural Pozzolan for Use in Concrete" American Society Tests of Material, 2019.
9. BS.1881:1992, "Standard test of Compressive strength of Concrete", British Standard Institution, 1992

10. ASTM C 496 "Standard Test Method for Splitting Tensile Strength of Cylindrical Concrete Specimens" American Society Tests of Material, 2017, Annual book of ASTM Standard, Volume 04.02 "ASTM international, West Conshohocken, PA, www.astm.org.

11. ASTM C78 "Standard Test Method for Flexural Strength of Concrete (Using Simple Beam with Third-Point Loading)" American Society Tests of Material, 2018, "Annual book of ASTM Standard, Volume 04.02" ASTM international, West Conshohocken, PA, www.astm.org.

12. ASTM C642 "Standard Test Method for Density, Absorption, and Voids in Hardened Concrete" American Society Tests of Material, 2013, "Annual book of ASTM Standard, Volume 04.02" ASTM international, West Conshohocken, PA, www.astm.org.

13. ASTM C597 "Standard Test Method for Pulse Velocity Through Concrete" American Society Tests of Material, 2002, "Annual book of ASTM Standard, Volume 04.02" ASTM international, West Conshohocken, PA, www.astm.org.

14. Dawood, E. T. and Ramli, M. (2014) Effects of the fibers on the properties of high strength flowing concrete. KSCE Journal of Civil Engineering 18(5), pp.1-7. DOI: 10.1007/s12205-014-0170-6

15. Dawood, E. T. and Ramli, M. (2014) "The effect of using high strength flowable system as repair material. Composites: Part B, 57, pp.91-95. https://doi. org/10.1016/j.compositesb.2013.09.048 